\title{
Giant Left Atrium Causing Acute Pulmonary Edema: A Case Report
}

\author{
Akut Akciğer Ödemine Neden Olan Dev Sol Atriyum: Bir Olgu Sunumu \\ Murat Duyan ${ }^{1}$, Serhat Gunlu ${ }^{2}$, Ali Saridas ${ }^{3}$, Resmiye Nur Okudan Kildan ${ }^{4}$, İbrahim Ulas Ozturan ${ }^{5}$ \\ ${ }^{1}$ Department of Emergency Medicine, Antalya Training and Research Hospital, Antalya, Turkey \\ ${ }^{2}$ Department of Cardiology, Dağkapı State Hospital, Diyarbakır, Turkey \\ ${ }^{3}$ Department of Emergency Medicine, Prof. Dr. Cemil Taşçığlu City Hospital, Istanbul, Turkey \\ ${ }^{4}$ Department of Emergency Medicine, Gebze Fatih State Hospital, Kocaeli, Turkey \\ ${ }^{5}$ Department of Emergency Medicine, Kocaeli University, Faculty of Medicine, Kocaeli, Turkey
}

\begin{abstract}
A patient who went through mitral valvuloplasty 11 years ago due to rheumatic heart disease was admitted to our hospital with progressive shortness of breath and lower extremity edema. There was atrial fibrillation in her ECG. Her heart rate was 154 beats/min on average. After the patient was stabilized, we applied imaging methods to find out the cause of the dyspnea. An increased cardiothoracic ratio was detected on an x-ray. The cardiothoracic index was measured as 0.78 on Chest X-ray. Transthoracic echocardiography and computed tomography of the thorax revealed that the cause was the giant left atrium. On the transthoracic echocardiogram performed, ejection fraction was $55 \%$, and it was found that the left atrium was approximately $19.7 \times 11.6 \mathrm{~cm}$ in the longitudinal short axis and it was compressing the left ventricle, right ventricle, and right atrium

In contrast-enhanced thorax computed tomography, in axial images, the anterior-posterior diameter of the left atrium was found to be $9 \mathrm{~cm}$, the transverse diameter was detected as 19.5 $\mathrm{cm}$, and the longitudinal diameter of the left atrium was measured as $15 \mathrm{~cm}$ in the measurements made from the middle of the transverse diameter in sagittal images

In this case report, we aimed to present a rare case of large left atrium seen by the emergency physician in a patient with pulmonary edema findings with preserved ejection fraction.
\end{abstract}

Key words: Giant left atrium, Rheumatic heart disease, Heart failure, Echocardiography, Dyspnea

\section{INTRODUCTION}

In the related literature, giant left atrium (GLA) has been described as a condition in which cardiothoracic ratio > 0.7 in Chest X-ray (CXR) with an atrial wall anteroposterior diameter $>80 \mathrm{~mm}$ on chest computerized tomography (CT) or > $65 \mathrm{~mm}$ as indicated by M-mode transthoracic echocardiography

\section{ÖZET}

11 yıl önce romatizmal kalp hastalığı nedeniyle mitral valvüloplasti ameliyatı olan hasta ilerleyici nefes darlığı ve alt ekstremite ödemi ile hastanemize başvurdu. Ekg'sinde atriyal fibrilasyon vardı Kalp hızı ortalama 154vuru/dk idi. Hasta stabil hale getirildikten sonra nefes darlığının nedenini öğrenmek için görüntüleme yöntemlerine başvurduk .Röntgende artmış kardiyotorasik oran tespit edildi. Kardiyotorasik indeks göğüs $X$-ray'de 0.78 olarak ölçüldü. Transtorasik ekokardiyografi ve toraks bilgisayarlı tomografisi, nedenin dev sol atriyum olduğunu gösterdi. Yapılan transtorasik ekokardiyogramda ejeksiyon fraksiyonu \%55 olup, sol atriyumun longitudinal kısa eksende yaklaşık $19.7 \times 11,6 \mathrm{~cm}$ boyutlarında olduğu ve sol ventrikül, sağ atriyum ve sağ ventriküle bası yaptığı saptandı. Kontrastlı toraks bilgisayarlı tomografisinde, aksiyel görüntülerde sol atriyum ön-arka çapı $9 \mathrm{~cm}$, enine çapı $19.5 \mathrm{~cm}$ sagital görüntülerde transvers çapın ortasından yapılan ölçümlerde sol atriyum çapı $15 \mathrm{~cm}$ olarak ölçüldü. Bu olgu sunumunda korunmuş ejeksiyon fraksiyonlu pulmoner ödem bulguları olan bir hastada acil hekimi tarafından nadir görülen büyük sol atriyum olgusunu sunmayı amaçladık.

Anahtar Kelimeler: Dev sol atriyum, Romatizmal kalp hastalığı, Kalp yetmezliği, Ekokardiyografi, Nefes darlığı

(TTE) (1). Another characteristic of GLA can be the presence of an atrium that is in contact with the right lateral side of the chest wall; concomitant atrial fibrillation can always be detected in such conditions. Usually, such patients suffer from shortness of breath. GLA is usually linked with a long-term rheumatic mitral valve insufficiency or mixed mitral disease having 
dominant insufficiency (2). Another possible factor that plays a role in its development might be cited as the weakening of the left atrial wall due to both increases in the left atrial pressure and rheumatic pancarditis (2).

Greater enlargement of the left atrium can result in a tendency to develop a variety of complications such as thrombus formation, thromboembolic events, hemodynamics, respiration, and sudden death (3).

In this case report, we aimed to present a patient with a giant left atrium with preserved ejection fraction and features associated with acute congestive heart failure in the emergency room.

\section{CASE REPORT}

A 58-year-old female patient with a history of rheumatic valvular disease and persistent atrial fibrillation was admitted to the emergency department with progressive shortness of breath and pitting edema in the lower extremities. The patient with congestive right heart failure characteristics was taken to the critical care area of the emergency department. Physical examination revealed the existence of bibasilar rales in the lungs, jugular venous fullness, and apical murmur with auscultation. An electrocardiogram showed atrial fibrillation with rapid ventilation response. The patient's vitals were recorded as $110 / 80 \mathrm{mmHg}$, respiratory rate 28 / min, pulse 135 beats / $\mathrm{min}$ irregular, fever 36.6 oxygen saturation $90 \%$.

At the time of admission, the patient was being treated with warfarin. The international normalized ratio (INR) was detected as 3.1. Vasodilator and diuretics were started after chest X-ray (CXR) was taken with a portable X-ray device (as the conservative treatment). On the patient's CXR, there were widespread opacity areas, and the right sinus was closed. Some possible pre-diagnoses were cardiomegaly, pleural effusion, pericardial effusion, the existence of an abnormal mass, or congestive heart failure although the findings were not directly indicating any of these likely diagnoses. The cardiothoracic index was measured as 0.78 on CXR (Figure 1A). In the anamnesis of the patient who was administered diuresis, it was determined that mitral valve replacement was performed 11 years ago due to rheumatic mitral valve disease, and dysphagia and weight loss were also detected in addition to dysphagia and fatigue for the last two months. The patient applied to the polyclinic 10 days ago with a complaint of hoarseness. In the coronary angiogram performed 6 years ago, it was noted that there were non-critical plaques in the coronary arteries and the left atrium diameter of $6.0 \times 5.8 \mathrm{~cm}$ in diameter was detected in the echocardiogram.

On the TTE performed at the bedside by the emergency room physician, ejection fraction (EF) was $55 \%$, and it was found that the left atrium was approximately $19.7 \times 11.6 \mathrm{~cm}$ in the longitudinal short axis and it was compressing the left ventricle, right ventricle, and right atrium (Figure 1B). These findings were then confirmed by TTE performed by the cardiologist. In addition, transthoracic echocardiography performed by the cardiologist revealed severe mitral valve stenosis. The pressure half-time and mitral valve area were measured as $0.8 \mathrm{~cm} 2$. The mean diastolic pressure gradient was calculated as $14 \mathrm{mmHg}$. Insignificant paravalvular regurgitation was observed on both sides of the bilateral prosthetic valve. Pulmonary artery systolic pressure was measured as $35 \mathrm{mmHg}$. Pro-brain natriuretic peptide (BNP) P-BNP $7183 \mathrm{pq} / \mathrm{mL}$ was detected in the patient, and heart failure with preserved EF was considered.

In contrast-enhanced thorax $\mathrm{CT}$, in axial images, the anterior-posterior diameter of the left atrium was found to be $9 \mathrm{~cm}$, the transverse diameter was detected as $19.5 \mathrm{~cm}$ (Figure 1C), and the longitudinal diameter of 



Figure 1A. Increased cardiothoracic index and left atrial size on X-ray 1B. Increased left atrial size on echocardiographic examination. A giant left atrium is seen. (LA is Left atrium and Ivot is the left ventricular outflow tract) 1C: Thorax computed tomography (CT), in axial images, the anterior-posterior diameter of the atrium (LA is left atrium, Ivot is the left ventricular outflow tract, $R V$ is right atrium, LV is left ventricle and MV is mitral valve) 1D:Thorax computed tomography (CT), longitudinal diameter of the left atrium (RV is right ventricle, $A A o$ is ascendina aorta, pulmonarv basal trunk and LA is left atrium)

the left atrium was measured as $15 \mathrm{~cm}$ in the measurements made from the middle of the transverse diameter in sagittal images (Figure 1D). No thrombus was detected. Our patient, who did not accept surgical treatment, was hospitalized in the coronary intensive care unit for administration of conservative treatment.

\section{DISCUSSION}

Such factors as long-term hemodynamic or electrical overload might lead to the development of GLA as an end-stage result. Rheumatic mitral valve disease including mitral stenosis or mitral insufficiency is found to be the most commonly associated condition with GLA $(4,5)$. Atrial fibrillation, which can be seen secondary to left atrial enlargement, further increases the overload in the left atrium and causes further dilation $(4,6)$.

In our patient, the left atrium size continued to increase after the mitral valvuloplasty operation she went through 11 years ago due to rheumatic heart disease. The normal left atrium is not located on the left side, rather it is in the middle part of the chest. When it grows, it moves to the right and left. It can compress the lung lobes, airways, left recurrent laryngeal nerve, esophagus, and caval veins $(2,7,8)$.

In our case, the underlying cause of the patient's shortness of breath, hoarseness, dysphagia, and jugular venous fullness was attributed to the compression of the left atrium resulting from its enlargement, and the resulting change in its location. 
In patients with GLA, the symptoms mentioned above are usually accompanied by atrial fibrillation. Lifelong anticoagulant therapy is required to prevent thrombosis $(4,9,10)$. Our patient was treated with warfarin. Since her INR value was 3.1, she did not exhibit any signs of thrombosis.

Focused cardiac ultrasound is a fast and reliable point of care ultrasonography protocol for patients presenting symptoms suggestive of congestive heart failure depending on the right or left ventricle in the emergency department (11). Ultrasound at the bedside, which is commonly available in modern emergency care settings, has assisted clinicians in expeditiously executing examinations and reaching treatment decisions at the point of care (12). Since the ejection fraction was found to be normal in our patient, heart failure with preserved ejection fraction was detected. Left atrial enlargement causing acute pulmonary edema could be misdiagnosed as pleural effusion, pericardial effusion, or the presence of an abnormal mass. However, thanks to the use of ultrasonography, which is widely used in emergency departments today, the giant left atrium, which explains all clinical findings, has been identified quickly and accurately.

\section{CONCLUSION}

Giant left atrium can be defined as a condition rarely encountered in clinical practice, which complicates and overlooks the correct diagnosis. In patients who apply to the emergency department with the complaint of, echocardiography or tomography imaging techniques in addition to chest $\mathrm{X}$-ray should make a more accurate diagnosis and start the treatment quickly.

Informed Consent: The patient gave her informed consent to the anonymous publication of data for scientific purposes.
Conflict of Interest: The authors declare that they have no conflict of interest.

Funding: The authors received no specific grant from any funding in the public, commercial, or not-for-profit sectors.

\section{REFERENCES}

1. Piccoli GP, Massini C, Di Eusanio et all. Giant left atrium and mitral valve disease: early and late results of surgical treatment in 40 cases. J Cardiovasc Surg (Torino). 1984 Jul-Aug;25(4):328-36.

2. Hurst JW. Memories of patients with a giant left atrium. Circulation. 2001 Nov 27;104(22):2630-1

3. Funk M, Perez M, Santana O. Asymptomatic giant left atrium. Clin Cardiol. 2010 Jun;33(6): E104-5.

4. Kim H, Park YA, Choi SM, et al. Associates and Prognosis of Giant Left Atrium; Single Center Experience. J Cardiovasc Ultrasound. 2017 Sep;25(3):84-90.

5. Pandit BN, Aggarwal P, Subramaniyan S, Gujral JS, Nath RK. Largest giant left atrium in rheumatic heart disease. J Cardiol Cases. 2020 Dec 24;24(1):10-13

6. El Maghraby A, Hajar R. Giant left atrium: a review. Heart Views. 2012 Apr;13(2):46-52.

7. Apostolakis E, Shuhaiber JH. The surgical management of giant left atrium. European Journal of Cardio-Thoracic Surgery. Volume 33, Issue 2, February 2008, Pages 182190,

8. Buğra, A.K., Kadiroğulları, E. \& Onan, B. Reduction plasty for giant left atrium causing dysphagia: a case report. Gen Thorac Cardiovasc Surg 69, 546-549 (2021).

9. Farman MT, Sial JA, Khan N, Rahu QA, Tasneem H, Ishaq $M$. Severe mitral stenosis with atrial fibrillation--a harbinger of thromboembolism. J Pak Med Assoc. 2010 Jun;60(6):439-43.

10. Xu Y, Zhao L, Zhang L, Han Y, Wang P, Yu S. Left Atrial Enlargement and the Risk of Stroke: A Meta-Analysis of Prospective Cohort Studies. Front Neurol. 2020 Feb 14;11:26.

11. Andrus $P$, Dean A. Focused Cardiac Ultrasound. Global Heart. 2013;8(4): :299-303.

12. Bhagra A, Tierney DM, Sekiguchi H, Soni NJ. Point-of-Care Ultrasonography for Primary Care Physicians and General Internists. Mayo Clin Proc. 2016 Dec;91(12):1811-1827.

Cite as: Duyan M, Gunlu S, Saridas A, Okudan Kildan RN,Ozturan IU. Giant Left Atrium Causing Acute Pulmonary Edema: A Case Report. Eskisehir Med J. 2022;3(1):27-30. 